\title{
A NEWLY RECOGNIZED SPECIES OF SQUALODON (MAMMALIA, CETACEA) FROM THE MIOCENE OF THE MIDDLE ATLANTIC COASTAL PLAIN
}

DOOLEY, Alton C., Jr., Louisiana State University Museum of Natural Science, 119 Foster Hall, Baton Rouge, LA 70803, U.S.A.

Of the approximately 18 squalodont species from the Western Atlantic Miocene which have been described prior to 1923, only Squalodon calvertensis Kellogg is based on good material. As a result, almost all squalodonts collected from these deposits have been referred to $S$. calvertensis. Since 1923 it has been noticed that a much larger squalodont was also present in the Calvert and Pungo River Formations, and that it was likely a different species. This material has usually been referred to $S$. tiedemani Allen, which was based on a large reworked rostrum fragment from South Carolina. It appears that these referrals were in error.

"Genus Y" of Whitmore and Sanders (1975) from the Oligocene of South Carolina has a rostrum very similar in size and shape to $S$. tiedemani. The teeth of Genus Y are also quite similar to Saurocetus gibbesii Agassiz, from the same deposits. The Saurocetus tooth is very different from squaoldont teeth, similar in shape but with much simpler enamel. As the morphologies of S. tiedemani and Saurocetus gibbesi are

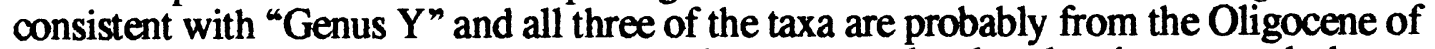
South Carolina, it is likely they represent the same or closely related non-squalodont taxa. Since the Miocene "S. tiedemani" material is distinctly squalodont in all aspects of its anatomy and S. tiedemani is probably not a squalodont, a new name is required for the large Miocene species.

The Miocene material includes two skulls, several mandibles, and a number of teeth. One of the skulls has an associated vertebral column. Unfortunately, no periotic is known, and the only tympanics are two isolated and reworked specimens which cannot be definitely referred to this species. Material is known from the western shore of the Chesapeake Bay in Maryland, the vicinity of the Potomac River in Maryland and Virginia, and the Lee Creek Mine in North Carolina. The new species is considerably larger than the largest $S$. calvertensis specimens. Overall similarity to $S$. calvertensis is great, with the same overall skull structure and apparently the same dentition, but there are some 12 characters separating the two species. The new species is quite rare relative to $S$. calvertensis, making up $10 \%$ or less of all North American squalodont specimens. It appears to be restricted to the Fairhaven Member of the Calvert Formation and its equivalents, unlike $S$. calvertensis which is found throughout the Calvert Formation. 